\title{
The influence of Lemna sp. and Spirogyra sp. on the removal of pharmaceuticals and endocrine disruptors in treated wastewaters
}

\author{
A. Garcia-Rodríguez $\cdot$ V. Matamoros • \\ C. Fontàs $\cdot$ V. Salvadó
}

Received: 13 March 2013/Revised: 16 January 2014 / Accepted: 13 May 2014/Published online: 7 June 2014

(C) Islamic Azad University (IAU) 2014

\begin{abstract}
The presence of pharmaceuticals and endocrine-disrupting chemicals (EDCs) in wastewater treatment plant effluents is an issue of great concern due to the negative effects that these compounds may have on human health and ecosystems. The present study aims to assess the capacity of two aquatic plants (Lemna sp. and Spirogyra sp.), commonly found in polishing ponds, for removing six pharmaceutical compounds (diclofenac, acetaminophen, ibuprofen, carbamazepine, clofibric acid, and propranolol), two EDCs (17 $\alpha$-ethinylestradiol and bisphenol A), and one stimulant (caffeine) under laboratory-scale conditions. Planted and unplanted reactors fed with secondary-treated wastewater or ultrapure water in both covered and uncovered conditions were studied. The highest removal efficiencies, which ranged from 31 to $100 \%$, were achieved in uncovered planted systems containing secondary-treated wastewater after 20 days of incubation. The results demonstrated that non-charged compounds with a log Kow between 2 and 4 were affected by the presence of vegetation, probably due to their plant uptake, whereas negatively charged compounds were not. This highlights that the presence of plants in polishing ponds plays an important role in the removal of pharmaceuticals and EDCs.
\end{abstract}

Electronic supplementary material The online version of this article (doi:10.1007/s13762-014-0632-x) contains supplementary material, which is available to authorized users.

A. Garcia-Rodríguez · C. Fontàs · V. Salvadó

Department of Chemistry, University of Girona, Campus

Montilivi, 17071 Girona, Spain

V. Matamoros ( $\square)$

IDAEA-CSIC, Jordi Girona, 18, 08034 Barcelona, Spain

e-mail: vmmqam@gmail.com
Keywords Aquatic plants - Endocrine-disrupting chemicals · Pharmaceuticals - Polishing ponds - Removal

\section{Introduction}

Pharmaceuticals and endocrine-disrupting chemicals (EDCs) are organic contaminants found in aquatic environments worldwide as they are incompletely removed in conventional treatment at wastewater treatment plants (WWTPs) (Giri et al. 2010; Hijosa-Valsero et al. 2010; Verlicchi et al. 2012). Examples of these compounds are oestrogens such as oestradiol and 17 $\alpha$-ethinylestradiol or plasticizers such as bisphenol A, which can mimic or block the action of endogenous hormones (Snyder et al. 2003) and pharmaceutical compounds such as ibuprofen, diclofenac, and carbamazepine that have been detected in surface waters and WWTP effluents at concentrations from the $n g \mathrm{~L}^{-1}$ range to up to several $\mu \mathrm{g} \mathrm{L}^{-1}$ (Ratola et al. 2012). In vitro and in vivo studies have found that active pharmaceutical compounds, whether individually or in combination, may have a negative ecotoxicological impact at the concentrations detected in the environment (Zuccato et al. 2006).

Conventional WWTPs are designed to remove organic matter and nutrients and cannot efficiently eliminate micropollutants such as pharmaceuticals and EDCs (Murray et al. 2010; Ratola et al. 2012). These limitations have led to the development of advanced oxidation processes such as $\mathrm{TiO}_{2}$-mediated heterogeneous photocatalysis, electrochemical oxidation, and sub-critical wet air oxidation to eliminate up to $99 \%$ of recalcitrant pharmaceutical compounds such as carbamazepine and clofibric acid (Deegan et al. 2011; Karthikeyan et al. 2012; Klavarioti et al. 2008). 
Nevertheless, advanced treatment processes require a high level of energy consumption and are expensive to build and maintain, and the water obtained from them is not as ecologically rich as that obtained through biologically-based treatments such as constructed wetlands or polishing ponds (Ávila et al. 2013; Li et al. 2013; Ortiz et al. 2011). These biologically-based water reclamation systems are typically located after secondary wastewater units and can be almost as effective as advanced treatment systems whilst avoiding the disadvantages of advanced systems (Imfeld et al. 2009; Matamoros and Salvadó 2012). A further advantage is that these systems efficiently eliminate certain pharmaceuticals (Hijosa-Valsero et al. 2010; Li et al. 2014; Matamoros et al. 2012a).

A variety of physical, chemical and biological processes such as sorption, biodegradation and photodegradation are associated with the removal of pharmaceuticals and EDCs in biologically-based wastewater treatments (Imfeld et al. 2009; Matamoros et al. 2008; White et al. 2006). These processes, which can occur concurrently, depend on the physicochemical properties of the compound to be eliminated and on the internal plant metabolism when organic pollutants are uptaken by plants. In the latter case, a serial chain of biochemical reactions can occur, including the transformation of parent pollutants, the conjugation of metabolites with macromolecules, and the incorporation of conjugated products into cell walls and vacuoles (PilonSmits 2005; Reinhold et al. 2010). Recent laboratory-scale studies carried out using ultrapure or tap water have found that aquatic plants (e.g. Lemna sp. and Ceratophyllum sp.) (Matamoros et al. 2012b; Reinhold et al. 2010) can enhance the removal of pharmaceuticals such as ibuprofen and caffeine, whereas in the case of diclofenac, sulfonamides and tetracyclines they are mainly removed by photodegradation (Andreozzi et al. 2003; Garcia-Rodríguez et al. 2013).

However, little attention has been paid neither to the effect of vegetation in the removal of other microcontaminants with different physicochemical properties nor to the combined role of vegetation, organic matter, microbial communities, and sunlight exposure in the removal of microcontaminants by polishing ponds. In the case of plants, there is also a lack of information on the differences between using superior rooted aquatic plants, such as Lemna sp., and filamentous algae, such as Spirogyra sp.

The aim of this study is to assess the capacity of polishing ponds to remove six pharmaceuticals (diclofenac, DCF; acetaminophen, ACAPh; ibuprofen, IBP; carbamazepine, CARB; clofibric acid, CLF AC; and propranolol, PROPR), two EDCs (17 $\alpha$-ethinylestradiol, 17-ET; and bisphenol A, BPA) and one stimulant (caffeine, CAFF). To this end, a laboratory-scale study was performed using different reactors, some containing aquatic vegetation
(Lemna sp. and Spirogyra sp.). As well as evaluating the removal capability of each reactor, the study identifies the different elimination processes taking place. The compounds were selected according to their ubiquity in WWTP effluents and different physicochemical properties (Table 1 in Supplementary Material, SM). The study was carried out at the research laboratory of the University of Girona (Spain) from September to December 2011.

\section{Materials and methods}

Description of the treatment plant

Biological samples (algae and duckweed) and secondarytreated wastewater samples were obtained from the Empuriabrava WWTP, which is located in the north-east of Spain and serves a mostly residential area with a ca 67,000 population equivalent. The WWTP undertakes pre-treatment, primary clarification, activated sludge treatment, and secondary clarification. After treatment, the water is pumped into the reclamation plant, which is composed of two parallel polishing ponds and a surface flow constructed wetland. The secondary-treated wastewater effluent had a conductivity of $3,000 \mu \mathrm{S} \mathrm{cm}^{-1}$, a $\mathrm{pH}$ of 8 , and a total concentration of suspended solids of $2 \mathrm{mg} \mathrm{L}^{-1}$.

Experimental design

Algae (Spirogyra sp.) and duckweed (Lemna sp.) were collected from the polishing pond of the same WWTP where secondary-treated wastewater samples were collected. Before initiating the experiment, these two plants were preacclimated to laboratory conditions in a $70-\mathrm{L}$ fish tank for a month.

The set-up of the laboratory-scale study included a series of planted and control reactors, some covered with aluminium foil and others uncovered, which were fed with either secondary-treated wastewater or reagent ultrapure water. A total of 18 reactors were used to allow three reactors for each set of conditions (see Fig. 1). Each system consisted of a glass reactor with $2.5 \mathrm{~L}$ of secondary-treated wastewater or ultrapure water. These reactors, which were randomly distributed, were left at room temperature $\left(20^{\circ} \mathrm{C}\right)$ and exposed to light from $36 \mathrm{~W}$ cool, white fluorescent tubes with a photon flux of $15 \mu \mathrm{mol} \mathrm{m} \mathrm{m}^{-2} \mathrm{~s}^{-1}$ in a $12 \mathrm{~h}$ light/darkness cycle.

A mixture of six pharmaceuticals, two EDCs, and one stimulant was added to each reactor to obtain a final concentration of $100 \mu \mathrm{g} \mathrm{L}^{-1}$ (1 mL of spiking solution at $250 \mathrm{mg} \mathrm{L}^{-1}$ of each compound in methanol). Ten milligrams fresh weight (fw) of algae and duckweeds were added to the corresponding containers. The experiments 
Fig. 1 Scheme of the experimental setup
Light

(36 W cool white fluorescent tubes)

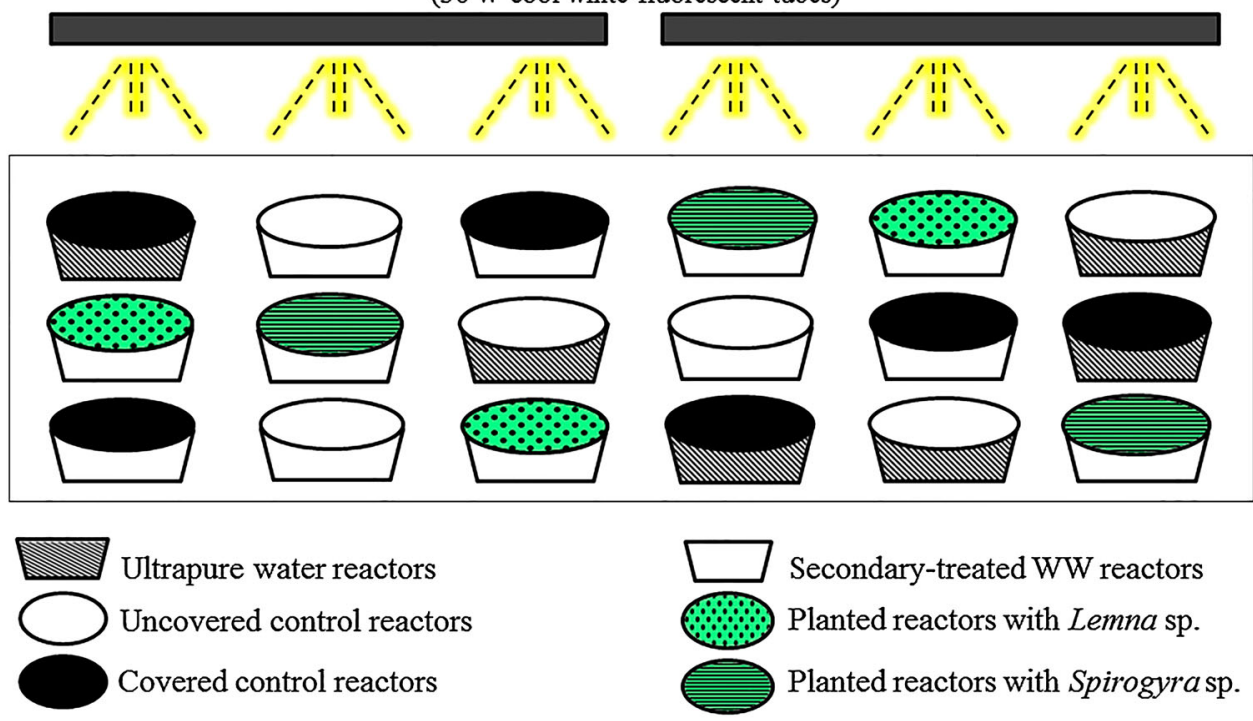

were run for 20 days. The fresh mass of the aquatic vegetation at the end of the experiment was about $20 \mathrm{~g}$ for Lemna sp. and $28 \mathrm{~g}$ for Spirogyra sp.

\section{Sampling strategy}

Aqueous samples of $1 \mathrm{~mL}$ were taken regularly during the 20 days that the experiment lasted. All samples were collected in clean brown glass bottles, filtered with PTFE filters and frozen until analysis. In order to keep the same depth of water in the reactors and correct for any losses, the reactors were refilled with secondary-treated wastewater to a pre-set mark before each sampling. The analytical methodology employed for the determination of target microcontaminants in water samples is given in the SM section.

Data analysis

Experimental results were analysed using SPSS V. 15 software (Chicago, IL, USA). The correlation coefficients of the concentration depletion of the polar microcontaminants as a function of time were calculated using parametric statistics (Pearson correlation coefficient). A principal component analysis (PCA) was conducted to treat the kinetic values obtained from the experimental data set. Once the data matrix was completed, it was autoscaled to have zero as the mean and unit variance (correlation matrix) in order to avoid problems arising from the different measurement scales and numerical ranges of the original variables. Varimax rotation was also used in the analysis.

\section{Results and discussion}

Behaviour of the selected microcontaminants

The variation in the concentration of the selected pharmaceuticals and EDCs in water throughout the experiments can be seen in Figs. 2, 3 and 4. Compounds were grouped according to their removal efficiencies in uncovered planted or unplanted reactors fed with secondary-treated wastewater. They were classified as follows, highly degradable compounds (CAFF and ACAPh) when removal efficiencies were around $100 \%$ in $<10$ days, moderately degradable compounds (BPA, 17-ET, IBP, and PROPR) when removal efficiencies ranged from 88 to $100 \%$ after 20 incubation days, and poorly degradable compounds (DCF, CLF AC, and CARB) when removal efficiencies ranged from 20 to $41 \%$ in 20 days. Afterwards, the results obtained for each of these groups were evaluated taking into account different parameters, such as the physicochemical properties of the compounds (e.g. log Kow, and pKa (Table 1-SM)), water composition (ultrapure water and secondary-treated wastewater), light effect (differences between the degradation profiles obtained from the covered and uncovered experiments fed with treated wastewater or ultrapure water) and plant effect (degradation profiles obtained from planted and unplanted reactors fed with secondary-treated wastewater).

Finally, the main processes affecting the removal of microcontaminants-biodegradation, photodegradation (direct or indirect), and plant uptake-are identified for each group, although it must be remembered that different removal processes can occur simultaneously in 
Fig. 2 Decline concentration of highly degradable compounds in the a covered control reactors fed with secondary-treated wastewater (inverted filled black triangles) or ultrapure water (filled black squares) and uncovered control reactors fed with secondary-treated wastewater (inverted filled green triangles) or ultrapure water (filled pink squares). b Lemna sp. (filled black circles), Spirogira sp (filled red circles) and uncovered control reactors fed with secondarytreated wastewater (inverted filled green triangles)
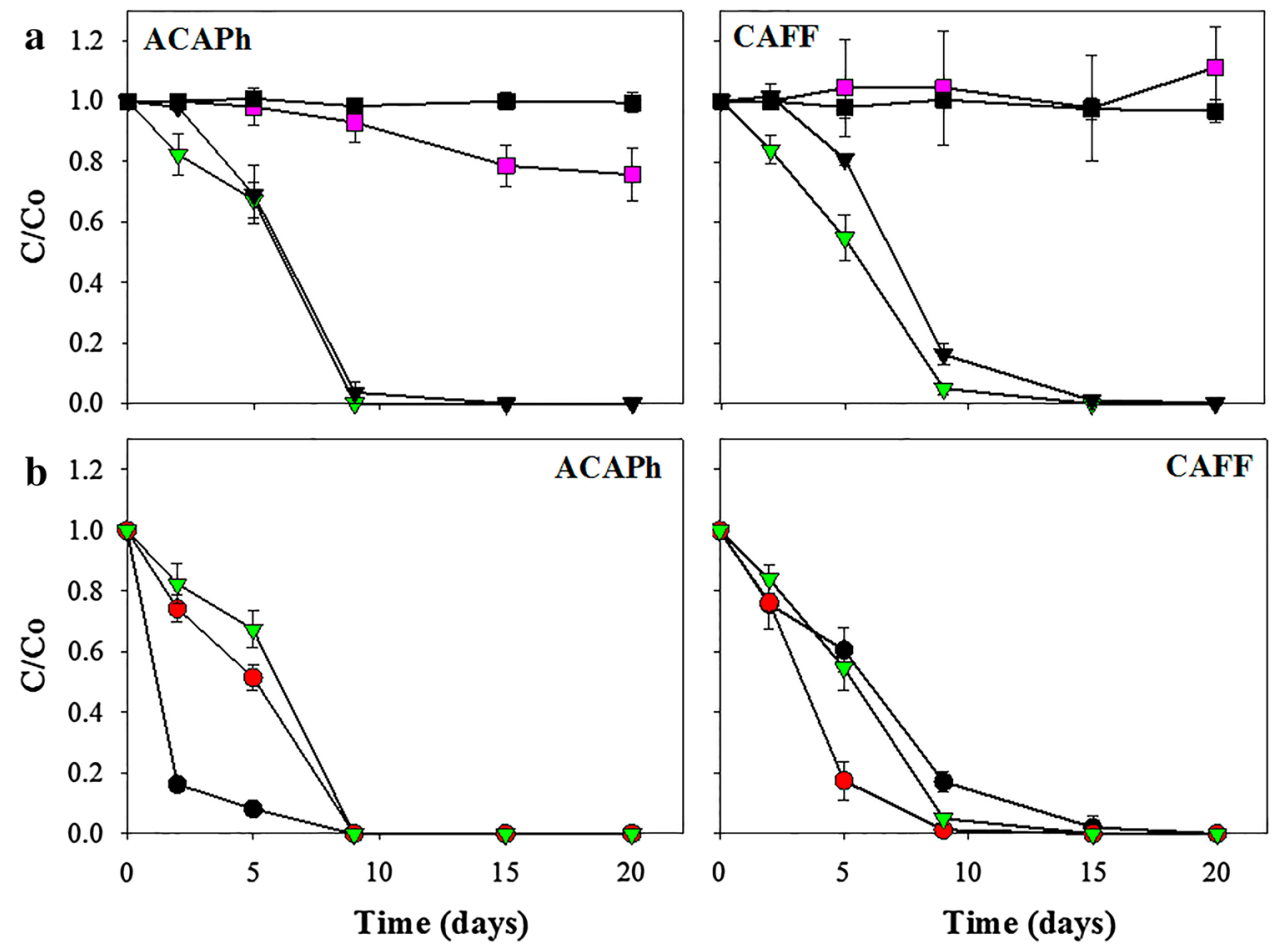

biologically-based wastewater treatment systems (Macek et al. 2000; Zhang et al. 2010).

\section{Highly degradable compounds}

Figure $2 \mathrm{a}$ and $\mathrm{b}$ show that after 10 days of incubation, almost complete elimination was obtained for both ACAPh and $\mathrm{CAFF}$ in all reactors filled with secondary-treated wastewater. Moreover, the reactors containing Lemna sp. and Spirogyra sp. presented the fastest elimination rates resulting in efficiencies of $84 \pm 1 \%$ in the removal of ACAPh after 2 days of incubation and of $83 \pm 8 \%$ in the removal of CAFF after 5 days of incubation. However, in reactors filled with ultrapure water, elimination was much lower ( $<25 \%$ after 20 days). Therefore, biodegradation and removal due to the presence of plants can be considered as the main processes involved in the elimination of $\mathrm{ACAPh}$ and CAFF. The presence of bacteria and organic matter in secondary-treated wastewater can enhance biodegradation of compounds such as ACAPh and CAFF, whose high biodegradation rates in surface waters and wastewaters have been reported in different studies (Conckle et al. 2008; Zhang et al. 2012a). Moreover, the presence of plants, producing exudates and containing microorganisms on their surfaces, aids the removal of these compounds through both biodegradation and plant uptake (Dordio et al. 2010; Reinhold et al. 2010). These results agree with those found by Matamoros et al. (2012a) for
CAFF in laboratory assays using hydroponic cultures as well as those obtained by Zhang et al. (2012b, 2013a) in a mesocosm study planted with Scirpus sp., in which removals of $>85 \%$ were achieved. The high polarity and lack of charge at environmental $\mathrm{pH}$ of both ACAPh and CAFF explain their uptake by aquatic plants (Trapp 2009). Zhang et al. (2013a) also observed that non-charged compounds, such as CAFF, were easily incorporated by Scirpus validus, an aquatic plant. Nevertheless, in comparison with previous laboratory studies with synthetic river water, the effect of vegetation on the removal of CAFF was much lower (Matamoros et al. 2012b). This can be explained by the differences in the water composition used in the different studies, as the content of organic matter and bacteria is, in general, higher in secondary-treated wastewater than surface water.

\section{Moderately degradable compounds}

Figure $3 \mathrm{a}$ and $\mathrm{b}$ show significant concentration declines for BPA, 17-ET, IBP, and PROPR in the uncovered reactors fed with secondary-treated wastewater. BPA, 17-ET and PROPR were removed more efficiently in planted than unplanted reactors during the first 10 days, with removal efficiencies ranging from 68 to $95 \%$. However, in the covered control reactors filled with the same type of water, the percentages of elimination were lower $(<34 \%)$. No elimination was observed in either covered or uncovered 
Fig. 3 Decline concentration of moderately degradable compounds in the a covered control reactors fed with secondary-treated wastewater (inverted filled black triangles) or ultrapure water (filled black squares) and uncovered control reactors fed with secondarytreated wastewater (inverted filled green triangles) or ultrapure water (filled pink squares). b Lemna sp (filled black circles), Spirogyra sp. (filled red circles) and uncovered control reactors fed with secondary-treated wastewater (inverted filled green triangles)
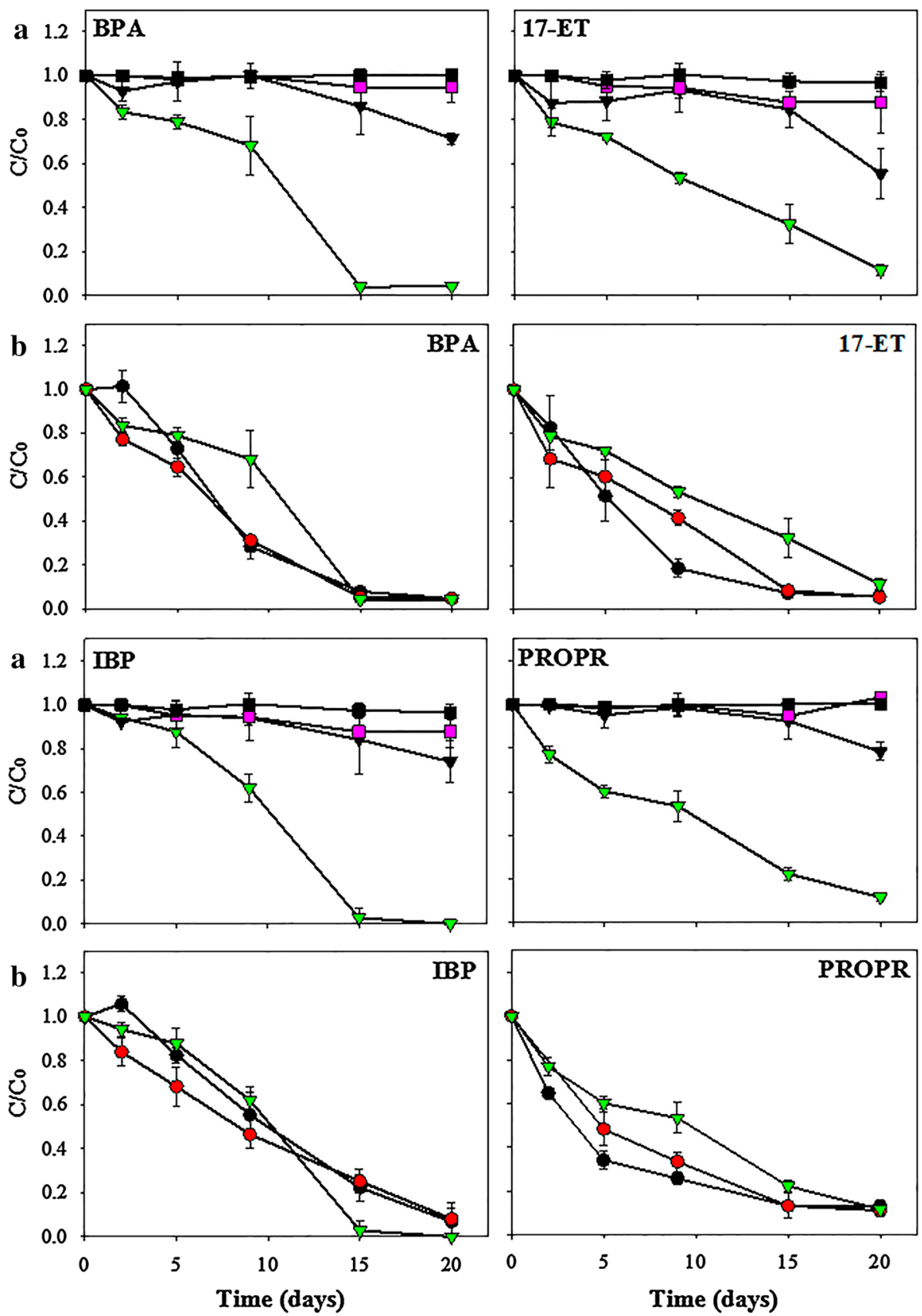

control reactors filled with ultrapure water. Based on these findings, it can be deduced that the presence of microorganisms, organic matter, nitrates, and other matrix components in the secondary-treated wastewater favours the removal of these compounds by indirect photodegradation or biodegradation, as has previously been reported by White et al. (2006) in constructed wetlands. Moreover, as stated by Ávila et al. (2013) and Kumar et al. (2011), in the presence of adequate photosensitizers, such as bacteria or plant exudates, BPA, 17-ET, IBP, and PROPR can be biodegraded or spontaneously photodegraded in natural waters, corroborating the high removal rates obtained in our study.

The differences observed between planted and unplanted reactors may be explained by indirect effects such as the presence of plant exudates and microbial activity associated with the biofilm development on the plants' surface or by the direct uptake of these compounds by the plants (Matamoros et al. 2012a, b). Moreover, as Spirogyra sp. grew in the uncovered reactors filled with secondary- 
Fig. 4 Decline concentration of poorly degradable compounds in the a covered control reactors fed with secondary-treated wastewater (inverted filled black triangles) or ultrapure water (filled black squares) and uncovered control reactors fed with secondary-treated wastewater (inverted filled green triangles) or ultrapure water (filled pink squares). b Lemna sp. (filled black circles), Spirogyra sp. (filled red circles) and uncovered control reactors fed with secondarytreated wastewater (inverted filled green triangles)
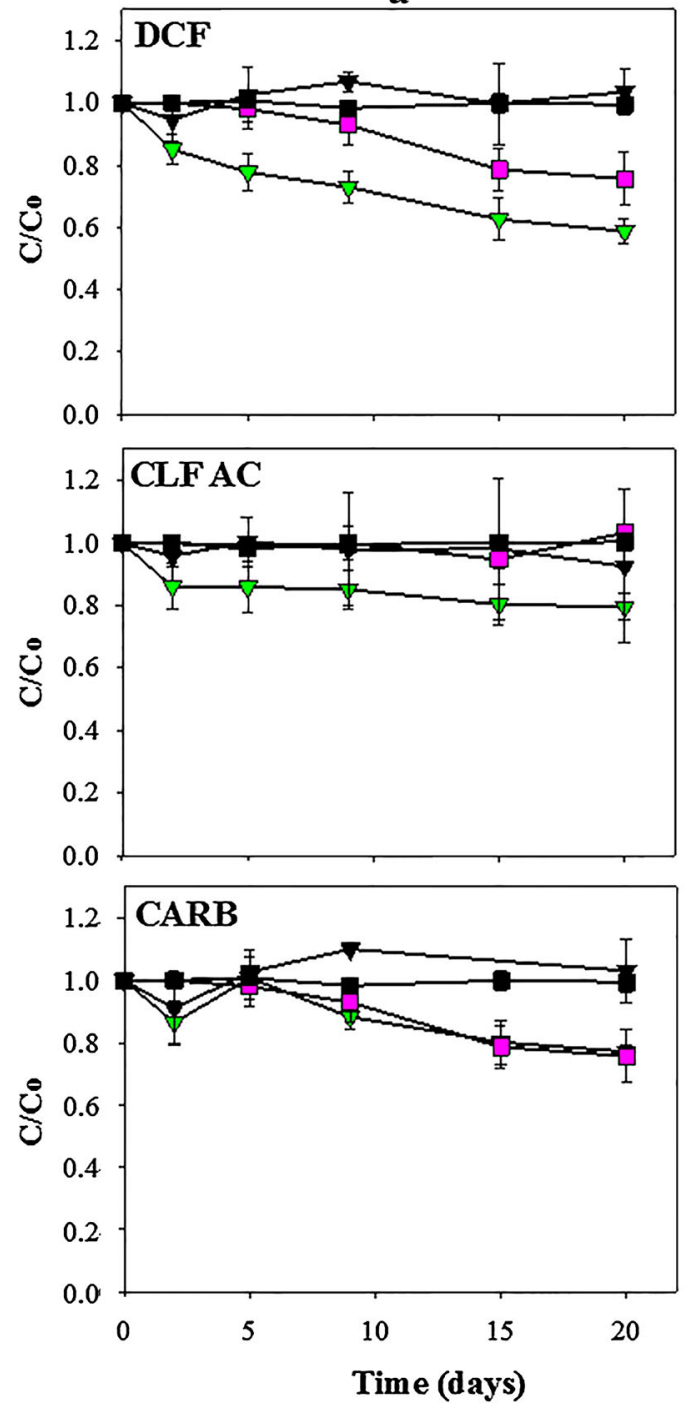

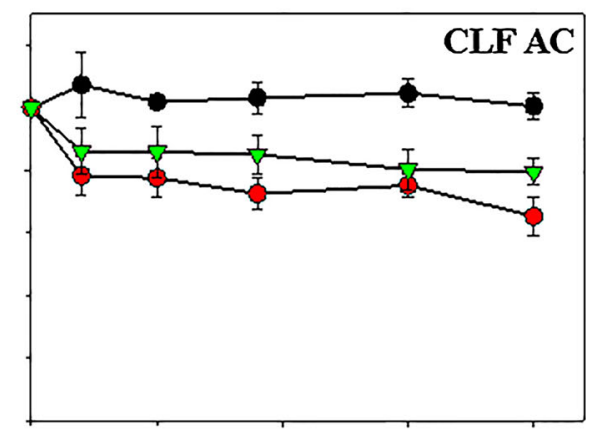

b
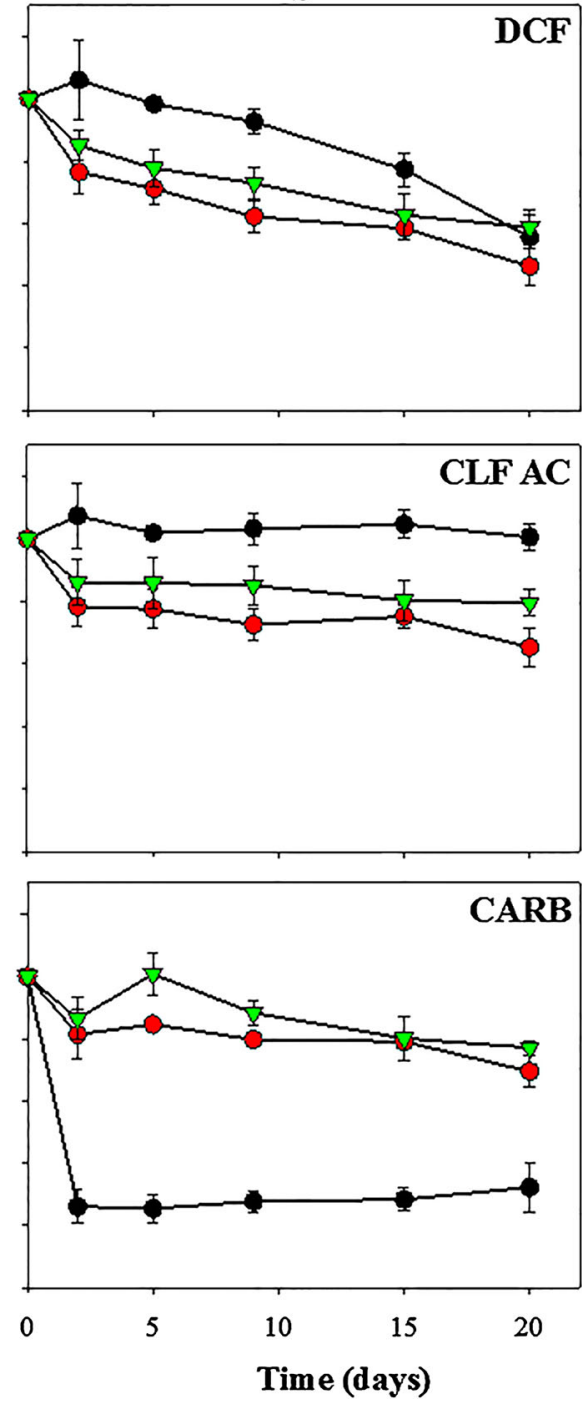

treated wastewater 10-15 days after starting the experiment, this plant may contribute to increasing the removal of contaminants, resulting in similar levels of elimination in both planted and unplanted reactors. In a laboratoryscale study, Shi et al. (2010) obtained removal efficiencies of $>80 \%$ for 17-ET when duckweed or algae was present in the water. Kumar et al. (2011) also obtained removal efficiencies of $>90 \%$ in a microcosm of a surface flow constructed wetland containing different type of plants. Ávila et al. (2010), when evaluating the capacity of horizontal flow constructed wetlands for the removal of emerging organic contaminants, achieved removals ranging from 85 to $99 \%$ for BPA and IBP, similar to the results obtained by $\mathrm{Li}$ et al. (2013) in a lagoon system where removals of 79-99 \% of IBP were obtained. These results suggest that non-charged compounds with a log Kow of between 3 and 4 (BPA, 17-ET, and PROP) are consistently uptaken by plants (Deegan et al. 2011), as it has been previously postulated by different authors for other compounds with similar log Kow (Pilon-Smits 2005; Tsao 2003). Moreover, sorption into solid particles must also be taken into account. The concentration decline observed in the different type of reactors for IBP, an ionic compound at environmental $\mathrm{pH}$ conditions, cannot be mainly associated to plant uptake as the electrical repulsion between the negative charge of anions and the negative charge of the biomembrane does not permit the plant uptake of ionized compounds (Trapp 2009). Therefore, indirect photodegradation and biodegradation are considered to be the main removal processes for IBP, whereas plant uptake and 
sorption on the surface of the vegetation and into solid particles are for non-ionized compounds such as BPA, 17-ET, and PROP (log Kow $=3-4)$.

\section{Poorly degradable compounds}

DCF, CLF AC, and CARB were the compounds found to have been least removed after the 20 experimental days with final removal rates of $<45 \%$. No significant differences were observed between the reactors compared with any of the studied compounds (Fig. 4a, b) except for DCF and CARB in uncovered and planted reactors, respectively, where the removal efficiencies were greater. The removal efficiencies obtained agree with the reported recalcitrance of these compounds (Matamoros and Salvadó 2012; Zhang et al. 2012b). However, as stated by Andreozzi et al. (2003), when some microcontaminants, such as DCF, are exposed to sunlight, they are photodegraded either by direct or indirect mechanisms, which is consistent with the higher removal efficiency observed for DCF in uncovered, light-exposed reactors. Moreover, some studies have reported the influence of sunlight radiation on the removal of DCF in natural lakes and biologically-based reclamation plants (Matamoros et al. 2012a).

The results obtained for CARB and CLF AC agree with their already stated high recalcitrance to biodegradation and photodegradation in surface waters, conventional activated sludge WWTPs and polishing ponds (Heberer 2002; Hijosa-Valsero et al. 2010; Matamoros and Salvadó 2012; Moldovan et al. 2009; Tixier et al. 2003). Finally, the greater elimination of CARB (71 $\pm 4 \%$ in 2 days) in reactors planted with Lemna sp. can be explained by the fact that this plant has roots that may facilitate its uptake $(\log$ Kow $=2.45)$. Conversely, plant uptake does not seem to be relevant for CLF AC, an ionic compound in environmental $\mathrm{pH}$ conditions (pKa 3.2). Dordio et al. (2010, 2011) also obtained high removals of CARB (88-97 \%) in the presence of rooted plants (Typha sp.) in a microcosm study and Zhang et al. (2013b) reported that CARB was easily incorporated to $S$. validus, an aquatic plant.

\section{Kinetics removal rates}

Table 1 shows the kinetic parameters obtained for the different experiments. The decay of the concentration of studied compounds in water under the different experimental conditions fits well with a pseudo-first order kinetic, which should be related to the effect of biodegradation and photodegradation processes, generally described as first order reactions (Matamoros et al. 2009). The simplified pseudo-first order equation used in this study is as follows: $\ln [A]=-k t+\ln [A]_{\mathrm{o}}$

where $[A]$ is the concentration of the compound at any moment of time, $[A]_{\mathrm{o}}$ is the initial concentration of the compound, $\mathrm{k}$ is the removal rate coefficient (in units of $1 /$ time), and $t$ is the time since the experiment started. Pseudo-first order removal rates were compound dependent and ranged from $<0.001$ to $0.503 \mathrm{day}^{-1}$ in reactors filled with secondary-treated wastewater and from $<0.001$ to $0.017 \mathrm{day}^{-1}$ in reactors filled with ultrapure water. These latest reactors were those which presented higher values of half-life for all the studied compounds (45 to $>800$ days). The lowest values were obtained for reactors fed with secondary-treated wastewater, whereas the greatest were for the control covered reactors, indicating that photodegradation had a large influence on compounds removal.

The uncovered reactors fed with secondary-treated wastewater showed the highest removal for CAFF, IBP and ACAPh ( $>99 \%$ after 20 incubation days), presenting pseudo-first order removal rates from 0.049 to 0.503 day $^{-1}$ and half-lives between 1 and 9 days. The values for CAFF and IBP calculated in this study were higher than those previously found in a laboratory-scale study with Lemna sp. incubated under synthetic surface water $(0.18$ and $0.02 \mathrm{day}^{-1}$, respectively) (Matamoros et al. 2012b). In the present study, the composition of the secondary-treated wastewater substantially enhanced the IBP kinetic removal rate values. Half-lives for BPA, 17-ET, IBP, and PROPR ranged from 4 to 14 days. In general, highest removal rates were obtained in uncovered reactors, ranging from 0.050 to $0.181 \mathrm{day}^{-1}$ for both IBP and BPA in unplanted uncovered reactors. The removal of these compounds is explained by biodegradation and indirect photodegradation processes taking place in the reactor. The kinetic rates obtained are similar to those reported in constructed wetlands for the removal of these compounds (Ávila et al. 2010; HijosaValsero et al. 2010; Kumar et al. 2011).

Recalcitrant compounds DCF, CLF AC and CARB showed the lowest removal efficiencies, as photodegradation, biodegradation, and plant uptake do not seem to be significant processes in the elimination of these compounds (Conckle et al. 2008; Matamoros and Salvadó 2012), and CLF AC was the most recalcitrant compound according to the half-life $\left(t_{1 / 2}=50\right.$ to $>800$ days). Nevertheless, it is worth mentioning that the kinetic rates of CLF AC seem to be affected by the presence of plants. In the case of CARB, the lowest half-life was achieved in reactors containing the 
Table 1 Kinetic parameters (rate constants and half-life times), correlation coefficients and percentage of removal of selected microcontaminants in the microcosms reactors

\begin{tabular}{|c|c|c|c|c|c|c|c|}
\hline Trade name (pKa, log Kow) & Type of water & Reactor & $K\left(\right.$ day $\left.^{-1}\right)$ & $\begin{array}{l}\text { Pearson } \\
\text { cor. coef. }\end{array}$ & $p$ value & $\begin{array}{l}t_{1 / 2} \\
\text { (days) }\end{array}$ & $\begin{array}{l}\text { Removal } \\
(\%)\end{array}$ \\
\hline \multirow{6}{*}{$\begin{array}{l}\text { Carbamazepine }(\mathrm{CARB}) \mathrm{pKa}=13.9 \\
\quad \log \mathrm{Kow}=2.3\end{array}$} & \multirow{4}{*}{$\begin{array}{l}\text { Secondary-treated } \\
\text { wastewater }\end{array}$} & Covered control & $0.006 \pm 0.001$ & 0.674 & 0.109 & 118 & $19 \pm 12$ \\
\hline & & $\begin{array}{l}\text { Uncovered } \\
\text { control }\end{array}$ & $0.011 \pm 0.002$ & 0.880 & 0.008 & 62 & $23 \pm 7$ \\
\hline & & Spirogyra sp. & $0.013 \pm 0.004$ & 0.799 & 0.041 & 58 & $31 \pm 5$ \\
\hline & & Lemna sp. & $0.035 \pm 0.001$ & 0.534 & 0.272 & 20 & $72 \pm 1$ \\
\hline & \multirow[t]{2}{*}{ Ultrapure } & Covered control & $<0.001$ & - & - & $>800$ & $\mathrm{nr}$ \\
\hline & & $\begin{array}{l}\text { Uncovered } \\
\text { control }\end{array}$ & $<0.001$ & - & - & $>800$ & $\mathrm{nr}$ \\
\hline \multirow{6}{*}{$\begin{array}{l}\text { Caffeine }(\mathrm{CAFF}) \mathrm{pKa}=10.4 \\
\log \mathrm{Kow}=0.07\end{array}$} & \multirow{4}{*}{$\begin{array}{l}\text { Secondary-treated } \\
\text { wastewater }\end{array}$} & Covered control & $0.300 \pm 0.010$ & 0.405 & 0.008 & 2 & $99 \pm 1$ \\
\hline & & $\begin{array}{l}\text { Uncovered } \\
\text { control }\end{array}$ & $0.337 \pm 0.042$ & 0.931 & 0.013 & 2 & $99 \pm 1$ \\
\hline & & Spirogyra sp. & $0.503 \pm 0.006$ & 0.979 & 0.047 & 1 & $99 \pm 1$ \\
\hline & & Lemna sp. & $0.185 \pm 0.016$ & 0.950 & 0.003 & 4 & $99 \pm 1$ \\
\hline & \multirow[t]{2}{*}{ Ultrapure } & Covered control & $<0.001$ & - & - & $>800$ & $\mathrm{nr}$ \\
\hline & & $\begin{array}{l}\text { Uncovered } \\
\text { control }\end{array}$ & $0.010 \pm 0.001$ & 0.925 & 0.005 & 67 & $16 \pm 1$ \\
\hline \multirow{6}{*}{$\begin{array}{l}\text { Acetaminophen }(\mathrm{ACAPh}) \mathrm{pKa}=9.4 \\
\operatorname{logKow}=0.46\end{array}$} & \multirow{4}{*}{$\begin{array}{l}\text { Secondary-treated } \\
\text { wastewater }\end{array}$} & Covered control & $0.076 \pm 0.025$ & 0.938 & 0.014 & 10 & $99 \pm 1$ \\
\hline & & $\begin{array}{l}\text { Uncovered } \\
\text { control }\end{array}$ & $0.079 \pm 0.017$ & 0.991 & 0.017 & 9 & $99 \pm 1$ \\
\hline & & Spirogyra sp. & $0.132 \pm 0.017$ & 0.996 & 0.019 & 5 & $99 \pm 1$ \\
\hline & & Lemna sp. & $0.479 \pm 0.026$ & 0.931 & 0.642 & 1 & $99 \pm 1$ \\
\hline & \multirow[t]{2}{*}{ Ultrapure } & Covered control & $<0.001$ & - & - & $>800$ & $\mathrm{nr}$ \\
\hline & & $\begin{array}{l}\text { Uncovered } \\
\text { control }\end{array}$ & $0.008 \pm 0.002$ & 0.639 & 0.049 & 86 & $24 \pm 7$ \\
\hline \multirow{6}{*}{$\begin{array}{l}\text { Propranolol (PROPR) pKa }=9.4 \\
\quad \operatorname{logKow}=3.09\end{array}$} & \multirow{4}{*}{$\begin{array}{l}\text { Secondary-treated } \\
\text { wastewater }\end{array}$} & Covered control & $0.011 \pm 0.002$ & 0.806 & 0.074 & 67 & $22 \pm 4$ \\
\hline & & $\begin{array}{l}\text { Uncovered } \\
\text { control }\end{array}$ & $0.093 \pm 0.010$ & 0.984 & 0.001 & 7 & $88 \pm 2$ \\
\hline & & Spirogyra sp & $0.120 \pm 0.022$ & 0.937 & 0.049 & 7 & $89 \pm 3$ \\
\hline & & Lemna sp. & $0.130 \pm 0.032$ & 0.946 & 0.032 & 8 & $87 \pm 2$ \\
\hline & \multirow[t]{2}{*}{ Ultrapure } & Covered control & $<0.001$ & - & - & $>800$ & $\mathrm{nr}$ \\
\hline & & $\begin{array}{l}\text { Uncovered } \\
\text { control }\end{array}$ & $0.003 \pm 0.002$ & 0,636 & 0.151 & 300 & $7 \pm 2$ \\
\hline \multirow{6}{*}{$\begin{array}{l}\text { Ibuprofen }(\mathrm{IBP}) \mathrm{pKa}=4.9 \\
\quad \operatorname{logKow}=3.50\end{array}$} & \multirow{4}{*}{$\begin{array}{l}\text { Secondary-treated } \\
\text { wastewater }\end{array}$} & Covered control & $0.009 \pm 0.002$ & 0.570 & 0.036 & 78 & $38 \pm 26$ \\
\hline & & $\begin{array}{l}\text { Uncovered } \\
\text { control }\end{array}$ & $0.049 \pm 0.008$ & 0.926 & 0.002 & 14 & $99 \pm 1$ \\
\hline & & Spirogyra sp. & $0.099 \pm 0.008$ & 0.982 & $<0.001$ & 7 & $92 \pm 7$ \\
\hline & & Lemna sp. & $0.109 \pm 0.008$ & 0.972 & $<0.001$ & 6 & $93 \pm 6$ \\
\hline & \multirow[t]{2}{*}{ Ultrapure } & Covered control & $<0.001$ & - & - & $>800$ & $\mathrm{nr}$ \\
\hline & & $\begin{array}{l}\text { Uncovered } \\
\text { control }\end{array}$ & $<0.001$ & - & - & $>800$ & $\mathrm{nr}$ \\
\hline \multirow{6}{*}{$\begin{array}{l}\text { Diclofenac }(\mathrm{DCF}) \mathrm{pKa}=4.2 \\
\quad \operatorname{logKow}=4.5\end{array}$} & \multirow{4}{*}{$\begin{array}{l}\text { Secondary-treated } \\
\text { wastewater }\end{array}$} & Covered control & $<0.001$ & - & - & $>800$ & $\mathrm{nr}$ \\
\hline & & $\begin{array}{l}\text { Uncovered } \\
\text { control }\end{array}$ & $0.024 \pm 0.003$ & 0.962 & 0.004 & 29 & $41 \pm 4$ \\
\hline & & Spirogyra sp & $0.032 \pm 0.004$ & 0.940 & 0.013 & 22 & $54 \pm 6$ \\
\hline & & Lemna sp & $0.029 \pm 0.004$ & 0.948 & 0.001 & 24 & $48 \pm 9$ \\
\hline & \multirow[t]{2}{*}{ Ultrapure } & Covered control & $<0.001$ & - & - & $>800$ & $\mathrm{nr}$ \\
\hline & & $\begin{array}{l}\text { Uncovered } \\
\text { control }\end{array}$ & $0.017 \pm 0.006$ & 0.919 & 0.002 & 45 & $24 \pm 9$ \\
\hline
\end{tabular}


Table 1 continued

\begin{tabular}{|c|c|c|c|c|c|c|c|}
\hline Trade name (pKa, log Kow) & Type of water & Reactor & $K\left(\right.$ day $\left.^{-1}\right)$ & $\begin{array}{l}\text { Pearson } \\
\text { cor. coef. }\end{array}$ & $p$ value & $\begin{array}{l}t_{1 / 2} \\
\text { (days) }\end{array}$ & $\begin{array}{l}\text { Removal } \\
(\%)\end{array}$ \\
\hline \multirow{6}{*}{$\begin{array}{l}\text { Clofibric acid (CLF AC pKa }=3.2 \\
\operatorname{logKow}=2.57\end{array}$} & \multirow{4}{*}{$\begin{array}{l}\text { Secondary-treated } \\
\text { wastewater }\end{array}$} & Covered control & $<0.001$ & - & - & $>800$ & $\mathrm{nr}$ \\
\hline & & $\begin{array}{l}\text { Uncovered } \\
\text { control }\end{array}$ & $0.009 \pm 0.001$ & 0.818 & 0.056 & 80 & $20 \pm 4$ \\
\hline & & Spirogyra sp. & $0.015 \pm 0.002$ & 0.806 & 0.063 & 48 & $35 \pm 6$ \\
\hline & & Lemna sp. & $<0.001$ & - & - & $>800$ & $\mathrm{nr}$ \\
\hline & \multirow[t]{2}{*}{ Ultrapure } & Covered control & $<0.001$ & - & - & $>800$ & $\mathrm{nr}$ \\
\hline & & $\begin{array}{l}\text { Uncovered } \\
\text { control }\end{array}$ & $<0.001$ & - & - & $>800$ & $\mathrm{nr}$ \\
\hline \multirow{6}{*}{$\begin{array}{l}\text { Bisphenol A (BPA) } \mathrm{pKa}=9.59-11.3 \\
\quad \log \mathrm{Kow}=3.69\end{array}$} & \multirow{4}{*}{$\begin{array}{l}\text { Secondary-treated } \\
\text { wastewater }\end{array}$} & Covered control & $0.014 \pm 0.002$ & 0.795 & 0.101 & 50 & $29 \pm 3$ \\
\hline & & $\begin{array}{l}\text { Uncovered } \\
\text { control }\end{array}$ & $0.181 \pm 0.012$ & 0.960 & 0.001 & 4 & $96 \pm 1$ \\
\hline & & Spirogyra sp & $0.174 \pm 0.002$ & 0.973 & 0.002 & 4 & $95 \pm 1$ \\
\hline & & Lemna sp. & $0.167 \pm 0.003$ & 0.988 & 0,002 & 4 & $96 \pm 1$ \\
\hline & \multirow[t]{2}{*}{ Ultrapure } & Covered control & $<0.001$ & - & - & $>800$ & $\mathrm{nr}$ \\
\hline & & $\begin{array}{l}\text { Uncovered } \\
\text { control }\end{array}$ & $<0.001$ & - & - & $>800$ & $\mathrm{nr}$ \\
\hline \multirow{6}{*}{$\begin{array}{l}\text { 17- } \alpha \text {-ethinylestradiol }(17-\mathrm{ET}) \mathrm{pKa}=10.5 \\
\quad \log \mathrm{Kow}=3.67\end{array}$} & \multirow{4}{*}{$\begin{array}{l}\text { Secondary-treated } \\
\text { wastewater }\end{array}$} & Covered control & $0.046 \pm 0.023$ & 0.722 & 0.008 & 18 & $45 \pm 11$ \\
\hline & & $\begin{array}{l}\text { Uncovered } \\
\text { control }\end{array}$ & $0.099 \pm 0.016$ & 0.949 & $<0.001$ & 7 & $88 \pm 3$ \\
\hline & & Spirogyra sp & $0.151 \pm 0.003$ & 0.984 & 0.003 & 5 & $94 \pm 1$ \\
\hline & & Lemna sp. & $0.155 \pm 0.006$ & 0.980 & 0.009 & 4 & $94 \pm 1$ \\
\hline & \multirow[t]{2}{*}{ Ultrapure } & Covered control & $<0.001$ & - & - & $>800$ & $\mathrm{nr}$ \\
\hline & & $\begin{array}{l}\text { Uncovered } \\
\text { control }\end{array}$ & $<0.001$ & - & - & $>800$ & $\mathrm{nr}$ \\
\hline
\end{tabular}

$n r$ no removal

rooted superior plant (Lemna sp., $t_{1 / 2}=20$ days) as has been discussed above (Dordio et al. 2011).

\section{PCA}

A principle component analysis (PCA) was performed using the whole data set in order to deepen our understanding of the main processes involved in the removal of selected contaminants in aquatic systems. The PCA reduced the nine measured variables to two principal components with eigenvalues $>1$, which explain $93 \%$ of the variability of the system. The first principal component (PC1) had positive loadings ( $>0.9)$ for CARB (1) and ACAPh (3), which presented the highest removal rates in Lemna sp. reactors fed with secondary-treated wastewater. The second component (PC2) had high positive values for CAFF (2) and CLF AC (7), which had the highest removal rates in Spirogyra sp. reactors fed with secondary-treated wastewater. The positive values of both $\mathrm{PC} 1$ and $\mathrm{PC} 2$ are associated with the greater removal efficiency that is achieved when aquatic plants are present in the reactors. The other compounds, 4, 5, 6, 8 , and 9 , had similarly positive values for both PC1 and PC2, indicating that the two plant species had similar effects on their removal rates.

Figure 5 is the scores plot for PC1 versus PC2. The six different experimental conditions were grouped into three clusters depending on the influence of the vegetation. Group I, which presented low values for both PC1 and PC2, consisted of covered control reactors fed with secondary-treated wastewater and the covered and uncovered control reactors fed with ultrapure water. No vegetation effect was observed in these reactors. Group II corresponds to the Lemma sp. reactors and finally Group III, which presented high positive values for PC2, was made up of Spirogyra sp. reactors and uncovered control reactors fed with secondary-treated wastewater. As has been mentioned above, the growth of Spirogyra sp. in the unplanted reactors explains their proximity to the group formed by reactors planted with algae. 


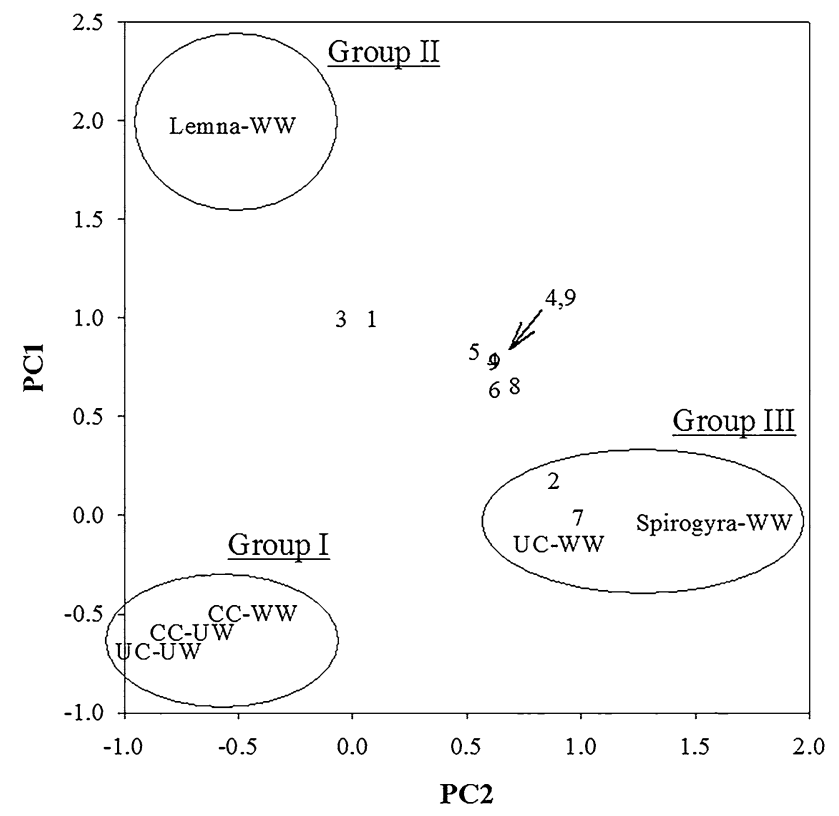

Fig. 5 Score plot of principal component 1 versus component 2 separating the reactor assays in three groups, namely the no vegetation effect (group I), the Lemna sp. effect (group II) and the Spirogyra sp. effect (group III). Loadings are also presented (1 CARB, 2 CAFF, 3 ACAPh, 4 PROPR, 5 IBP, 6 DCF, 7 CLF AC, 8 BPA, 9 17-ET). CC control covered, $U C$ uncovered control, $W W$ secondary-treated wastewater, $U W$ ultrapure water

\section{Conclusion}

The compounds studied are grouped according to their removal efficiencies in uncovered reactors filled with secondary-treated wastewater after 20 incubation days: highly degradable compounds (CAFF and ACAPh) when removal efficiencies were near to $100 \%$ in $<10$ days, moderately degradable compounds (BPA, 17-ET, IBP, and PROPR) when removal efficiencies ranged from 88 to $100 \%$ after 20 days, and poorly degradable compounds (DCF, CLF $\mathrm{AC}$, and $\mathrm{CARB}$ ) when removal efficiencies ranged from 20 to $41 \%$ after 20 days. Pseudo-first order removal rates ranged from 0.001 to $0.503 \mathrm{day}^{-1}$, with half-lives between 2 and $>800$ days. Finally, a PCA was successfully employed for the determination of the specific positive effect of Lemnna sp. on the removal rate of CARB and $\mathrm{ACAPh}$, as well as the effectiveness of algae on CAFF and CLF AC removal. Furthermore, this study has demonstrated that non-charged compounds with a log Kow between 2 and 4 (BPA, 17-ET, CARB and PROP) were affected by the presence of vegetation, probably due to their plant uptake, whereas negatively charged compounds
(IBP, DCF, and CLF AC) were not. Hence, we can conclude that the presence of aquatic plants can play an important role in the removal efficiency of pharmaceuticals and EDCs from polishing ponds and that the selection of the most appropriate plant species should be made in function of the compounds that are to be eliminated.

Acknowledgments The financial support of the Ministerio de Ciencia e Inovación through project CTM2011-28765-C02-02 is gratefully acknowledged. Aida Garcia-Rodríguez thanks the University of Girona for research Grant BR2011/27. Dr. V. M. would like to acknowledge a JAE-Doc contract from the CSIC and the European Social Fund.

\section{References}

Andreozzi R, Raffaele M, Nicklas P (2003) Pharmaceuticals in STP effluents and their solar photodegradation in aquatic environment. Chemosphere 50(10):1319-1330

Ávila C, Pedescoll A, Matamoros V, Bayona JM, García J (2010) Capacity of a horizontal subsurface flow constructed wetland system for the removal of emerging pollutants: an injection experiment. Chemosphere 81:1137-1142

Ávila C, Reyes C, Bayona JM, García J (2013) Emerging organic contaminant removal depending on primary treatment and operational strategy in horizontal subsurface flow constructed wetlands: influence of redox. Water Res 47(1):315-325

Conckle JL, White JR, Metcalfe CD (2008) Reduction of pharmaceutically active compounds by a lagoon wetland wastewater treatment system in Southeast Louisiana. Chemosphere 73(11):1741-1748

Deegan AM, Shaik B, Nolan K, Urell K, Oelgemöller M, Tobin J, Morrissey A (2011) Treatment options for wastewater effluents from pharmaceutical companies. Int $\mathrm{J}$ Environ Sci Technol 8(3):649-666

Dordio A, Palace Carvalho A, Teixeira D, Barrocas Dias C, Pinto A (2010) Removal of pharmaceuticals in microcosms constructed wetlands using Typha spp. and LECA. Bioresour Technol 101:886-892

Dordio AV, Belo M, Teixeira DM, Carvalho AJP, Dias CMB, Picó Y, Pinto AP (2011) Evaluation of carbamazepine uptake and metabolization by Typha spp., a plant with potential use in phytotreatment. Bioresour Technol 102(17):7827-7834

Garcia-Rodríguez A, Matamoros V, Fontàs C, Salvadó V (2013) The influence of light exposure, water quality and vegetation on the removal of sulfonamides and tetracyclines: a laboratory-scale study. Chemosphere 90(8):2297-2302

Giri RR, Ozaki H, Ota S, Takanami R, Taniguchi S (2010) Degradation of common pharmaceuticals and personal care products in mixed solutions by advanced oxidation techniques. Int J Environ Sci Technol 7(2):251-260

Heberer T (2002) Occurrence, fate and removal of pharmaceutical residues in the aquatic environment: a review of recent research data. Toxicol Lett 131(1-2):5-17

Hijosa-Valsero M, Matamoros V, Martín-Villacorta J, Bécares E, Bayona JM (2010) Assessment of full-scale natural systems for 
the removal of PPCPs from wastewater in small communities. Water Res 44(5):1429-1439

Imfeld G, Braeckevelt M, Kuschk P, Richnow HH (2009) Monitoring and assessing processes of organic chemicals removal in constructed wetlands. Chemosphere 74:349-362

Karthikeyan S, Gupta VK, Boopathy R, Titus A, Sekaran G (2012) A new approach for the degradation of high concentration of aromatic amine by heterocatalytic Fenton oxidation: kinetic and spectroscopic studies. J Mol Liq 173:153-163

Klavarioti M, Mantzavinos D, Kassinos D (2008) Removal of residual pharmaceuticals from aqueous systems by advanced oxidation processes. Environ Int 35(2):402-417

Kumar KA, Chiranjeevi P, Mohanakrishna G, Mohan SV (2011) Natural attenuation of endocrine-disrupting estrogens in an ecologically engineered treatment system (EETS) designed with floating, submerged and emergent macrophytes. Ecol Eng 37(10): $1555-1562$

Li X, Zheng W, Kelly WR (2013) Occurrence and removal of pharmaceutical and hormone contaminants in rural wastewater treatment lagoons. Sci Total Environ 445-446:22-28

Li Y, Zhu G, Ng WJ, Tan SK (2014) A review on removing pharmaceutical contaminants from wastewater by constructed wetlands: design, performance and mechanism. Sci Total Environ 468-469:908-932

Macek T, Macková M, Kás J (2000) Exploitation of plants for the removal of organics in environmental remediation. Biotechnol Adv 18(1):23-34

Matamoros V, Salvadó V (2012) Evaluation of the seasonal performance of a water reclamation pond-constructed wetland system for removing emerging contaminants. Chemosphere 86(2):111-117

Matamoros V, García J, Bayona JM (2008) Organic micropollutant removal in a full-scale surface flow constructed wetland fed with secondary effluent. Water Res 42(3):653-660

Matamoros V, Duhec A, Albaigés J, Bayona JM (2009) Photodegradation of carbamazepine, ibuprofen, ketoprofen and 17-ethinylestradiol in fresh and seawater. Water Air Soil Pollut 196(1-4):161-168

Matamoros V, Sala L, Salvadó V (2012a) Evaluation of a biologically-based filtration water reclamation plant for removing emerging contaminants: a pilot plant study. Bioresour Technol 104:243-249

Matamoros V, Nguyen XL, Arias C, Salvadó V, Brix H (2012b) Evaluation of aquatic plants for removing polar microcontaminants: a microcosm experiment. Chemosphere 88(10):1257-1264

Moldovan Z, Chira R, Alder AC (2009) Environmental exposure of pharmaceuticals and musk fragrances in the Somes River before and after upgrading the municipal wastewater treatment plant Cluj-Napoca, Romania. Environ Sci Pollut Res 16(1):46-54
Murray KE, Thomas SM, Bodour AA (2010) Prioritizing research for trace pollutants and emerging contaminants in the freshwater environment. Environ Pollut 158:3462-3471

Ortiz J, Merseburger GC, Matamoros V, Salvadó V, Colom J, Sala L, Camas J, Kampf R (2011) Regeneración de agua mediante filtración por cultivos de Daphnia en el sistema de mesocosmos de la EDAR de Empuriabrava. Tecnología del agua 330:57-65

Pilon-Smits E (2005) Phytoremediation. Annu Rev Plant Biol 56:15-39

Ratola N, Cincinelli A, Alves A, Katsoyiannis A (2012) Occurrence of organic microcontaminants in the wastewater treatment process. A mini review. J Hazard Mater 239-240:1-18

Reinhold D, Vishwanathan S, Park JJ, Oh D, Saunders M (2010) Assessment of plant-driven removal of emerging organic pollutants by duckweed. Chemosphere 80(7):687-692

Shi W, Wang L, Rousseau DPL, Lens PNL (2010) Removal of estrone, $17 \alpha$-ehinylestradiol, and $17 \beta$-estradiol in algae and duckweed-based wastewater treatment systems. Environ Sci Pollut R 17:824-833

Snyder SA, Westerhoff P, Yoon Y, Sedlak DL (2003) Pharmaceuticals, personal care products and endocrine disruptors implications for the water industry. Environ Eng Sci 20(5):449-469

Tixier C, Singer HP, Oellers S, Müller SR (2003) Occurrence and fate of carbamazepine, clofibric acid, diclofenac, ibuprofen, ketoprofen and naproxen in surface waters. Environ Sci Technol 37(6):1061-1068

Trapp S (2009) Bioaccumulation of polar and ionizable compounds in plants. In: Devillers J (ed) Ecotoxicology modeling. Spinger, USA, pp 299-353

Tsao DT (2003) Phytoremediation. In: Tsao DT (ed) Advances in biochemical engineering biotechnology. Springer, Germany

Verlicchi P, Al Aukidy M, Zambello E (2012) Occurrence of pharmaceutical compounds in urban wastewater: removal, mass load and environmental risk after secondary treatment-a review. Sci Total Environ 429:123-155

White JR, Belmont MA, Metcalfe CD (2006) Pharmaceutical compounds in wastewater: wetland treatment as a potential solution. Sci World J 6:1731-1736

Zhang BY, Zheng JS, Sharp RG (2010) Phytoremediation in engineered wetlands: mechanisms and applications. Procedia Environ Sci 2:1315-1325

Zhang DQ, Gersberg RM, Zhu J, Hua T, Jinadasa KBSN, Tan SK (2012a) Batch versus continuous feeding strategies for pharmaceutical removal by subsurface flow constructed wetland. Environ Pollut 167:124-131

Zhang DQ, Gersberg RM, Hua T, Zhu J, Tuan NA, Tan SK (2012b) Pharmaceutical removal in tropical subsurface flow constructed wetlands at varying hydraulic loading rates. Chemosphere $87: 273-277$ 
Zhang DQ, Hua T, Gersberg RM, Zhu J, Ng WJ, Tan SK (2013a) Fate of caffeine in mesocosm wetland planted with Scirpus validus. Chemosphere 90(4):1568-1572

Zhang DQ, Hua T, Gersberg RM, Zhu J, Ng WJ, Tan SK (2013b) Carbamazepine and naproxen: fate in wetland mesocosms planted with Scirpus validus. Chemosphere 91:14-21
Zuccato E, Castiglioni S, Fanelli R, Reitano G, Bagnati R, Chiabrando C, Pomati F, Rossetti C, Calamari D (2006) Pharmaceuticals in the environment in Italy: causes, occurrence, effects and control. Environ Sci Pollut Res 13(1):15-21 